\title{
Effect of pelagic larval growth and size-at-hatching on post-settlement survivorship in two temperate labrid fish of the genus Symphodus
}

\author{
N. Raventos*, E. Macpherson \\ Centro de Estudios Avanzados de Blanes (CSIC), C. acc. Cala Sant Francesc 14, 17300 Blanes, Girona, Spain
}

\begin{abstract}
The characteristics of fish larvae affect settlement and recruitment survival. We examined the effects of the variation in the early life characteristics (pelagic larval growth, pelagic larval duration, size-at-hatching and size-at-settlement) on post-settlement survival in 2 littoral species of the genus Symphodus (S. roissali and S. ocellatus) in the NW Mediterranean over 2 yr. We used otoliths to back-calculate growth rates and other early life traits exhibited by individuals at settlement and 2 mo after settlement. Size-at-hatching clearly affected the post-settlement survival of the 2 species. Juvenile survivors of $S$. roissali and $S$. ocellatus were mostly larger at hatching than settlers, and recently settled individuals were susceptible to size-selective mortality. Our study, however, showed that other larval traits (pelagic larval duration, larval otolith growth, size-at-age, size-at-settlement) were not always consistent with the growth-mortality hypothesis.
\end{abstract}

KEY WORDS: Size selection · Post-settlement mortality - Larval growth - Early larval traits · Labridae $\cdot$ Otoliths

Resale or republication not permitted without written consent of the publisher

\section{INTRODUCTION}

One of the main objectives of research on fish populations is to identify the factors that determine the number of new individuals recruited to the adult stage each year (year-class strength) (e.g. Doherty \& Fowler 1994, Caley et al. 1996, Macpherson et al. 1997, Caselle 1999). In some species, mortality rates in juvenile stages are size-selective, and small fish have a lower survivorship than larger ones of the same age, which gives cause to the 'growth-predation theory' or the 'bigger is better concept' (Anderson 1988, Bailey \& Houde 1989, Leggett \& DeBlois 1994). This is usually explained because, when mortality is size-dependent, fast-growing larvae and settlers are exposed to predators for a shorter period than those that grow more slowly. These processes have been studied by analysing some early life traits (e.g. growth rate, larval duration, size-at-hatching, size-at-settlement). Individuals with rapid growth (e.g. Meekan \& Fortier 1996,
Hare \& Cowen 1997, Searcy \& Sponaugle 2000, 2001, Shima \& Findlay 2002) and/or with a larger size-athatching (Vigliola \& Meekan 2002) have a higher survivorship than those with a lower growth rate and/or smaller size-at-hatching. Consequently, those that grow more quickly contribute more efficiently to the year-class strength and recruitment success (Bergenius et al. 2002, Wilson \& Meekan 2002). However, other studies have questioned the generality of 'the growth-predation theory' (Litvak \& Leggett 1992, Pepin et al. 1992) and others have shown that the intensity of size-selective mortality may vary from year to year (Meekan \& Fortier 1996).

In spite of the interest in elucidating the effect of early life traits on fish settlement, few studies have examined these processes (e.g. Meekan \& Fortier 1996, Hare \& Cowen 1997, Searcy \& Sponaugle 2001, Shima \& Findlay 2002, Vigliola \& Meekan 2002, Wilson \& Meekan 2002). Here, we examined the effects of variation in the early life characteristics (pelagic larval 
growth, pelagic larval duration, size-at-hatching and size-at-settlement) on post-settlement survival in 2 littoral species of the genus Symphodus (S. roissali and S. ocellatus) in the NW Mediterranean over 2 yr. We hypothesise that if 'the growth-predation theory' is applicable to these species, then we will observe that post-settlement survivorship is significantly dependent on their early life characteristics.

\section{MATERIALS AND METHODS}

Study species. Symphodus roissali and S. ocellatus are small species $(<15 \mathrm{~cm})$ that are quite common at shallow depths ( 0 to $15 \mathrm{~m}$ ) on rocky bottoms and in seagrass beds in the Mediterranean Sea (e.g. HarmelinVivien \& Francour 1992, Macpherson et al. 2002). Spawning takes place in nests built and defended by the dominant males (Van den Berghe 1990, Raventos 2004). In $S$. roissali mating activity begins at the end of March and ends in mid-June, while in S. ocellatus it runs from late May to early July. Settlement in these 2 species occurs always on branching algae, at depths shallower than $8 \mathrm{~m}$ (García-Rubies \& Macpherson 1995), when individuals have attained a size of around 5 to $7 \mathrm{~mm}$ (Raventos \& Macpherson 2001). Planktonic larval duration (PLD) is short in both species, lasting 11 to $14 \mathrm{~d}$ in $S$. roissali and 8 to $11 \mathrm{~d}$ in $S$. ocellatus (Raventos \& Macpherson 2001), and larvae are retained nearshore (Sabatés et al. 2003).

Sampling protocol. Field sampling was performed along the shore off Blanes, Spain $\left(41^{\circ} 40^{\prime} 9^{\prime \prime} \mathrm{N}\right.$, $2^{\circ} 47^{\prime} 9^{\prime \prime} \mathrm{E}$, NW Mediterranean), at depths between 3 and $6 \mathrm{~m}$ over a 2 yr period (2001 and 2002). We collected individuals of the 2 species at settlement, 0 to $2 \mathrm{~d}$ after settlement, ca. 5 to $7 \mathrm{~mm}$ (the 'settlement' group) and juveniles, 60 to $70 \mathrm{~d}$ after settlement, ca. 3 to $4 \mathrm{~cm}$ (the 'juvenile' group). Settlement sampling was conducted daily from 1 April to 31 July in 2001 and 2002. These dates spanned the entire settlement periods for the 2 species in the area (Raventos \& Macpherson 2005). Settlement of Symphodus roissali began in mid-April in 2001 and in mid-May in 2002 and ended in mid-June in both years, whereas settlement of $S$. ocellatus began at the end of June and ended in midJuly in both years. New settlers of $S$. roissali and $S$. ocellatus were collected using cores $\left(400 \mathrm{~cm}^{2}\right.$ in crosssectional surface area, $5 \mathrm{l}$ volume) taken from drifting algal accumulations, where the new settlers were commonly observed (Raventos \& Macpherson 2005).

Juveniles of the 2 species were collected by divers using hand-nets. These juveniles were sampled at the end of July (Symphodus roissali) and at the end of August (S. ocellatus). They were always found around branched algae, and were easily recorded and col- lected. To avoid sampling biases (Vigliola \& Meekan 2002), we collected all individuals from algal patches situated ca. $300 \mathrm{~m}$ from the sampling area of new settlers. Algal patches (ca. 5 to $10 \mathrm{~m}^{2}$ ) were haphazardly selected to conduct diving and sampling.

Otolith analysis. At the laboratory, all new settlers and juveniles were identified and measured to the nearest $0.01 \mathrm{~mm}$, and the otoliths (lapilli) were extracted and mounted in an oil droplet on a microscope slide. Age readings were made, and the presence of settlement marks were determined using a light microscope connected to a digital camera and image analysis system, following the standard methodology described by various authors (e.g. Wellington \& Victor 1992, Raventos \& Macpherson 2001).

Eggs of both species were reared in aquaria to determine whether the first growth increment was laid down on the first day of the larval stage. This yielded both the date of formation of the first band (the same as the date of hatch) and the daily pattern of band deposition. Based on these experiments, band deposition was confirmed to take place daily from the first day of hatch. Settlement marks were always clear in these species and belonged to Type III, a gradual settlement mark with optical contrast between the pre- and post-settlement zones (Wilson \& McCormick 1999, Raventos \& Macpherson 2001).

Each otolith was read twice, and when the readings differed by more than $2 \mathrm{~d}$, the otoliths were discarded ( $<5 \%$ discarded for each species, see also below). Ages of settlers and juvenile survivors were used to backcalculate the birthdate frequency distribution of each group. We analysed the otoliths along the longest radius from the centre to the edge, and recorded otolith width for each day during the pelagic larval period. This procedure was repeated 3 times to minimise measurement errors. We also recorded the size-at-hatching (the first increment), size-at-settlement and PLD.

A total of 204 individuals of Symphodus roissali and 202 S. ocellatus was used in the analyses (S. roissali, 137 individuals in 2001 [86 new settlers and 51 twomo-old juveniles] and 67 individuals in 2002 [34 and 33, respectively]; S. ocellatus, 106 individuals in 2001 [55 and 51, respectively] and 96 individuals in 2002 [50 and 46, respectively]).

Data analysis. To avoid biases in back-calculating somatic growth (Vigliola et al. 2000), we based comparisons of early traits, growth rate and size on otolith measurements (Hare \& Cowen 1997, Searcy \& Sponaugle 2001).

In order to know if fish that arrived early in the settlement period (first half) differ from those that arrived late (second half), we compared early larval traits between these 2 cohorts. No significant differences were found between the cohorts for otolith size-athatching, otolith growth rate, size-at-settlement or 
age-at-settlement ( $t$-test, $\mathrm{p}>0.05$ in all cases). These results were observed in both years of study. Therefore all data were considered together.

Selective mortality on the basis of early traits for each species was examined by comparison of the growth trajectory of the cohort back-calculated from the otoliths from each group (settlers and juveniles).

Cochran's test was used to determine the optimal transformation to improve normality and homogeneity of variance of the data. Repeated MANOVAs (multivariate analyses of variance) were used to compare estimates of the growth trajectory and length-at-age of the 2 groups (Chambers \& Miller 1995, Meekan \& Fortier 1996). Wilks' $\lambda$ was used as the test statistic (see also Searcy \& Sponaugle 2001). The number of individuals in this design guaranteed its statistical power, since it complied with the constraints recommended by Maxwell \& Delaney (1990) and Von Ende (1993). To determine whether there was selective mortality based on age-athatching, pelagic larval duration and size-at-settlement, we compared settler versus juvenile groups using standard ANOVA (analysis of variance) techniques (e.g. Searcy \& Sponaugle 2001, Vigliola \& Meekan 2002). Power tests to measure the adequacy of sample sizes on all non-significant ANOVA results were considered using the Pearson \& Hartley method (Zar 1984).

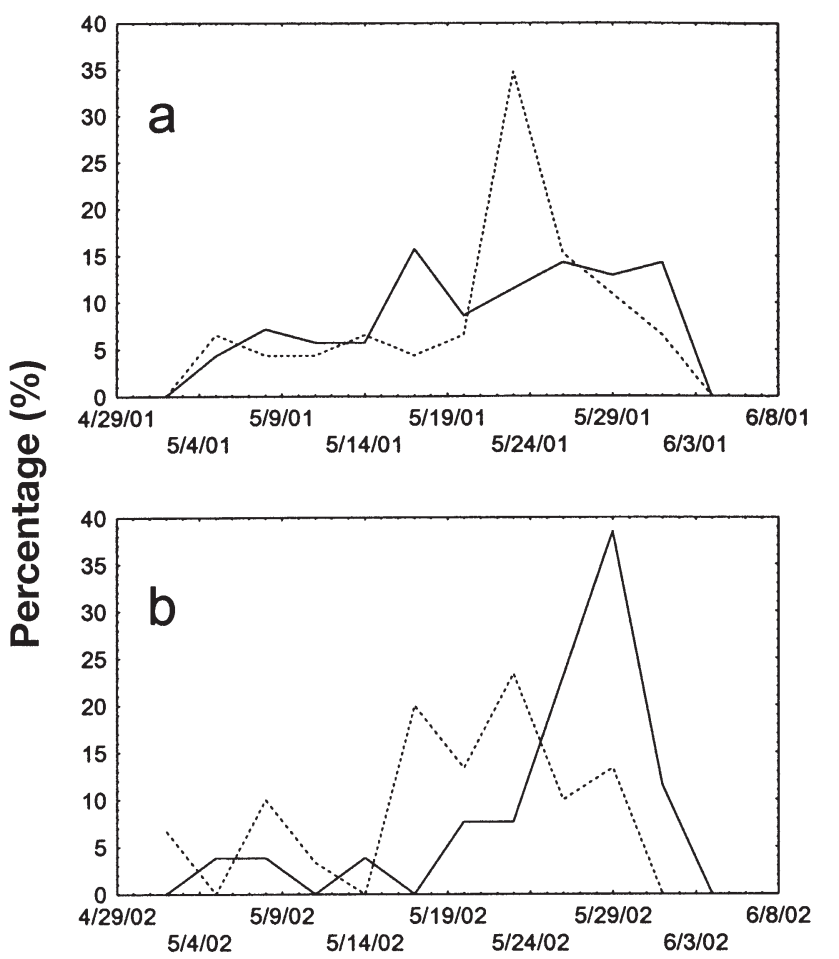

\section{RESULTS}

The relationship between otolith length and body length was highly significant (least-squares-fit regression) for both species of Symphodus, indicating that otolith radii along their longest axes were good predictors of the standard length of fishes. The relationships were: for $S$. roissali fish length $=0.35+0.0058$ (otolith radii) $\left(\mathrm{r}^{2}=0.80, \mathrm{p}<0.001, \mathrm{n}=130\right)$ and for $S$. ocellatus fish length $=0.38+0.0086$ (otolith radii) $\left(\mathrm{r}^{2}=0.75, \mathrm{p}<\right.$ $0.001, \mathrm{n}=93$ ).

The birthdate frequency distributions of settlers and juvenile survivors of both species overlap each other (Fig. 1), indicating that juvenile populations are formed by individuals arriving from the entire settlement period.

The growth of Symphodus roissali was initially fast until $3 \mathrm{~d}$ after hatching, after which it decreased rapidly until 6 to $7 \mathrm{~d}$ after hatching, increasing again thereafter (Fig. 2a,c). Juveniles (2 mo after hatching) of this species exhibited consistently faster growth and larger size-at-age than settlers only in 2001. At all ages, individuals in the juvenile group were larger than those that belonged to the settler group (Fig. 2a,b). These trends, however, did not differ significantly in 2002 (repeated-measures MANOVA,
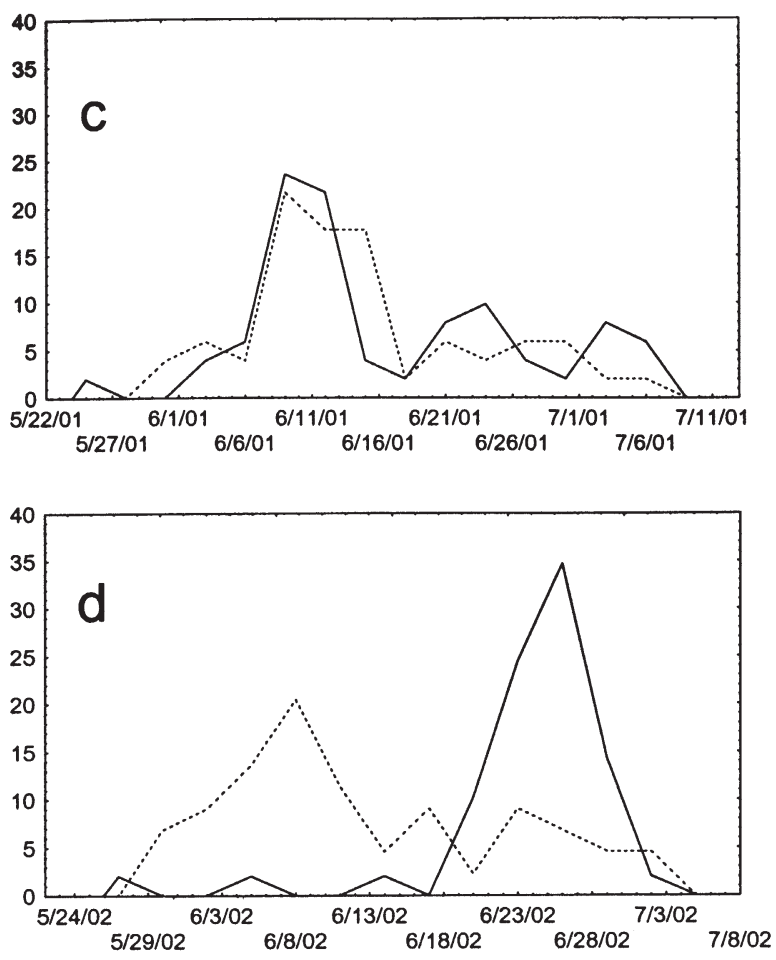

\section{Date $(\mathrm{mm} / \mathrm{dd} / \mathrm{yy})$}

Fig. 1. (a,c) Symphodus roissali and (b,d) S. ocellatus birthdate frequency distributions (\%) of settlers (solid line) and juveniles (dashed line) 


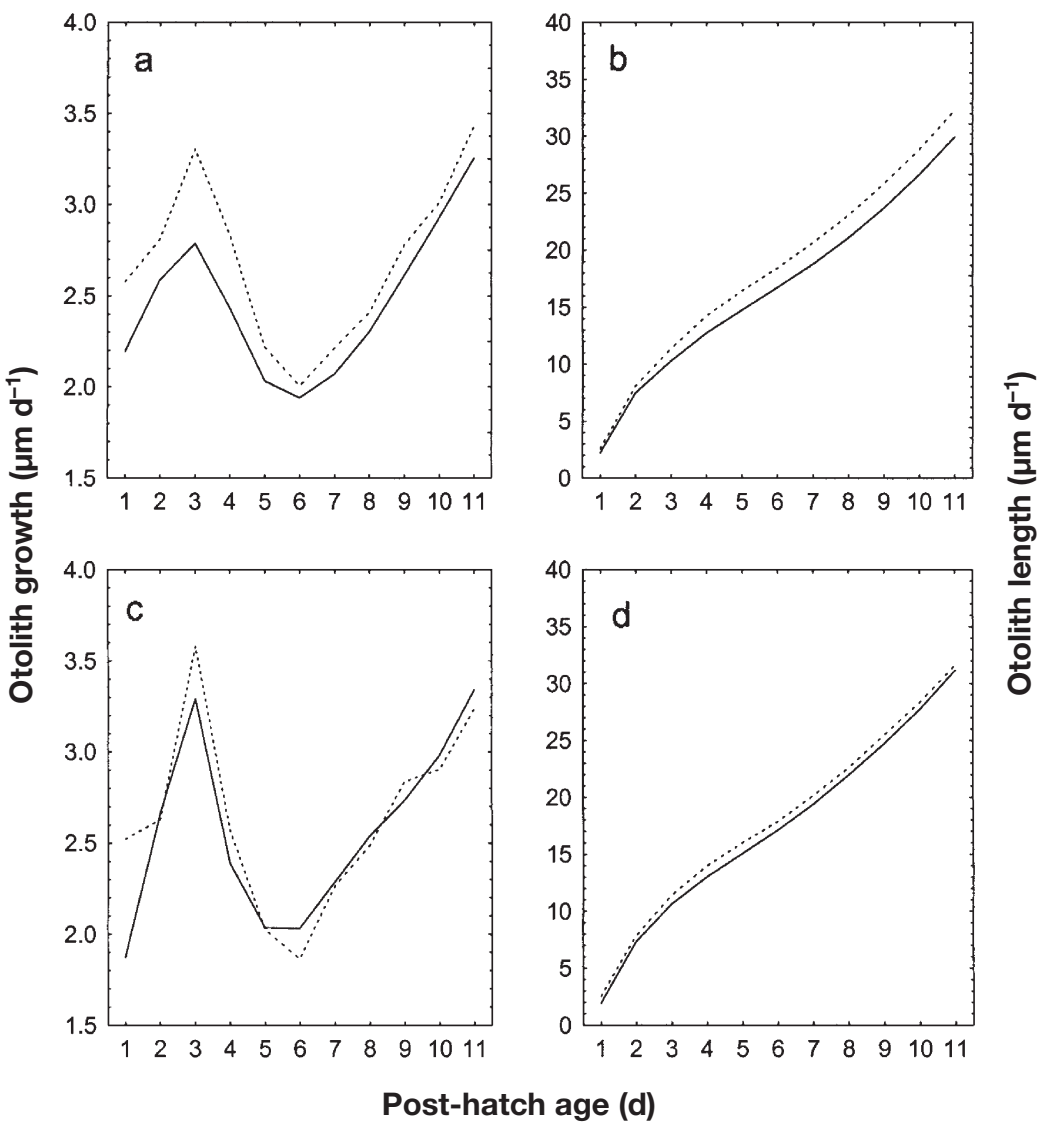

Fig. 2. Symphodus roissali. Mean larval otolith growth rate trajectories $\left(\mu \mathrm{m} \mathrm{d}^{-1}\right)$ and length-at-age $(\mu \mathrm{m})$ for settlers (solid line) and 1 mo old juveniles (dashed line). (a,b) Year 2001; (c,d) year 2002

Table 1. Symphodus roissali and S. ocellatus. Results of repeated-measures MANOVA comparisons of larval otolith length and growth of settlement group (Set) versus juvenile group (Surv) (2 mo after settlement)

\begin{tabular}{|lcccccc|}
\hline & Measure & df & Wilks' $\lambda$ & $F$ & $p$ & Trend \\
\hline S. roissali & & & & & & \\
2001 & Length & 10,108 & 0.825 & 20.12 & 0.0001 & Set < Surv \\
& Growth & & 0.898 & 11.23 & 0.001 & Set < Surv \\
2002 & Length & 11,57 & 0.87 & 1.90 & 0.174 & - \\
& Growth & & 0.68 & 0.51 & 0.477 & - \\
S. ocellatus & & & & & & \\
2001 & Length & \multirow{2}{*}{8,98} & 0.909 & 0.15 & 0.697 & - \\
2002 & Growth & & 0.914 & 0.35 & 0.556 & - \\
& Length & 8,88 & 0.553 & 11.89 & 0.0009 & Set $>$ Surv \\
& Growth & & 0.507 & 33.30 & 0.0001 & Set $>$ Surv \\
\hline
\end{tabular}

significantly different for juveniles (ANOVA, Table 2). In only a single year (2001) was the otolith size in the settlement group significantly higher than that in the juvenile group (ANOVA, p $<0.001$, Table 2). In contrast, size-at-hatching was significantly higher for the juvenile group in the 2 years of sampling (ANOVA, p $<0.001$, Table 2).

The initial growth trajectory for Symphodus ocellatus showed a similar pattern to that of $S$. roissali. Growth increased until Day 3 after hatching, decreased slowly until Days 6 to 7 and increased thereafter (Fig. 3a,c). However, no significant differences in larval otolith growth and size-at-age between settlers and juveniles were observed in 2001 (repeated-measures MANOVA, Fig. 3a,b, Table 1). In contrast, the results in 2002 showed significant differences in these 2 traits between settlers and juveniles. However, contrary to expected results, settlers grew faster and had larger size-at-age than juveniles (repeated-measures MANOVA, Fig. 3b,d, Table 1). In addition, no significant differences in size-at-hatching, PLD or size-at-settlement were observed in 2001 (ANOVA, Table 2). In contrast, in 2002, the width of the otolith band at hatching was significantly wider for juveniles than settlers (ANOVA, p $<0.01$, Table 2), while the PLD was shorter for juveniles and length-atsettlement was significantly greater for settlers (ANOVA, $\mathrm{p}<0.001$, Table 2).

For both species, the power of the ANOVA, which usually falls below the desired power of 0.8 (Zar 1984), opens the possibility that non-significant differences could be attributable in some cases to sample size. However, given the small magnitude of the differences between mean values and the relatively small standard deviations characterising non-significant results (Table 2), larger sample sizes would be unlikely to change the significance of the tests.

Fig. 1, Table 1). Settlers in 2002 showed faster growth than juveniles only until Day 5 after hatching (Fig. 2c). Furthermore, size-at-age did not differ significantly between the 2 groups (Fig. 2d). PLD was not
PLD was negatively correlated with size-at-hatching and size-at-settlement in both species and in both years (regression coefficients were always significant, $\mathrm{p}<0.01$ in all cases, although explaining a 
Table 2. Symphodus roissali and S. ocellatus. Data and results of ANOVA of early life-history traits of settlement group (Set) versus juvenile group (Juv). NS: not significant

\begin{tabular}{|c|c|c|c|c|c|c|c|}
\hline \multirow[t]{2}{*}{ Group } & \multirow[t]{2}{*}{$\mathrm{n}$} & \multicolumn{2}{|c|}{ Size-at-hatching $(\mu \mathrm{m})$} & \multicolumn{2}{|c|}{ Pelagic larval duration (d) } & \multicolumn{2}{|c|}{ Otolith length-at-settlement $(\mu \mathrm{m})$} \\
\hline & & Mean (SD) & ANOVA & Mean (SD) & ANOVA & Mean (SD) & ANOVA \\
\hline \multicolumn{8}{|c|}{ S. roissali } \\
\hline \multicolumn{8}{|c|}{2001} \\
\hline Set & 86 & $1.94(0.64)$ & \multirow[t]{2}{*}{0.0006} & $12.57(1.73)$ & \multirow[t]{2}{*}{ NS } & $35.11(4.19)$ & \multirow[t]{2}{*}{0.00004} \\
\hline Juv & 51 & $2.34(0.56)$ & & $12.78(1.55)$ & & $39.11(3.96)$ & \\
\hline \multicolumn{8}{|l|}{2002} \\
\hline Set & 34 & $1.66(0.82)$ & \multirow[t]{2}{*}{0.0007} & $12.20(1.49)$ & \multirow[t]{2}{*}{ NS } & $36.29(3.28)$ & \multirow[t]{2}{*}{ NS } \\
\hline Juv & 33 & $2.37(0.46)$ & & $12.76(1.25)$ & & $37.14(3.13)$ & \\
\hline \multicolumn{8}{|c|}{ S. ocellatus } \\
\hline \multicolumn{8}{|l|}{2001} \\
\hline Set & 55 & $1.62(0.54)$ & \multirow[t]{2}{*}{ NS } & $10.30(1.09)$ & \multirow[t]{2}{*}{ NS } & $37.13(3.05)$ & \multirow[t]{2}{*}{ NS } \\
\hline Juv & 51 & $1.66(0.44)$ & & $10.20(0.89)$ & & $37.25(4.10)$ & \\
\hline \multicolumn{8}{|l|}{2002} \\
\hline Set & 50 & $1.46(0.56)$ & \multirow[t]{2}{*}{0.004} & $10.53(1.12)$ & \multirow[t]{2}{*}{0.0001} & $35.47(3.12)$ & \multirow[t]{2}{*}{0.02} \\
\hline Juv & 46 & $1.75(0.39)$ & & $9.36(0.92)$ & & $33.92(3.26)$ & \\
\hline
\end{tabular}

low percentage of the variance, $\mathrm{r}^{2}$ ranging between 0.04 and 0.16). However, size-at-hatching was never related to size-at-settlement $\left(\mathrm{r}^{2}<0.01\right.$ and $\mathrm{p}>0.5$ in all cases).

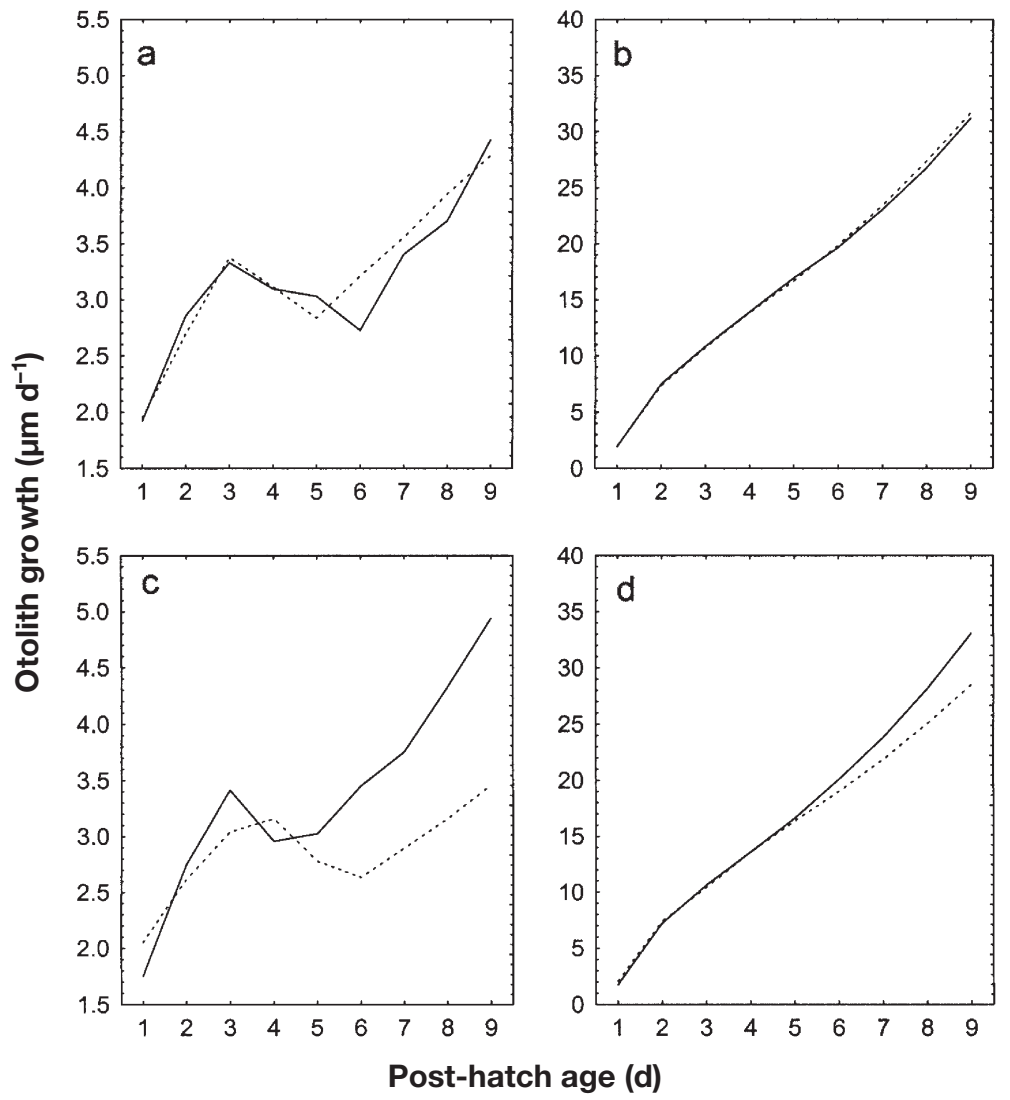

Fig. 3. Symphodus ocellatus. Mean larval otolith growth rate trajectories ( $\mu \mathrm{m}$ $\mathrm{d}^{-1}$ ) and length-at-age $(\mu \mathrm{m})$ for settlers (solid line) and 1 mo old juveniles (dashed line). (a,b) Year 2001; (c,d) year 2002

\section{DISCUSSION}

Size-at-hatching usually affects the post-settlement survival of Symphodus roissali and S. ocellatus. Juvenile survivors of these 2 species showed larger sizes-at-hatching than settlers, and generally revealed that recently settled individuals are susceptible to size-selective mortality. Our results, however, showed that other larval traits (pelagic larval duration, larval otolith growth, size-at-age, size-at-settlement) were not always related to size-athatching, nor were they consistent with the growth-mortality hypothesis of Anderson (1988). Although most of these traits are correlated each other (Sogard 1997, Searcy \& Sponaugle 2001, Shima \& Findlay 2002, Vigliola \& Meekan 2002), our results indicated that only size-at-hatching predicted the presence of selective mortality. The absence of a clear pattern in the comparison of growth trajectories and related indices (planktonic larval duration and size-at-settlement) between settlers and juveniles indicates that the intensity of size-selective mortality may also vary from year to year, as reported for Gadus morhua (Meekan \& Fortier 1996).

This selective mortality has been observed in other newly settled fishes. Individuals of Pomatomus saltatrix with faster growth have a higher probability 
of survival (Hare \& Cowen 1997). In addition, the feeding conditions of juvenile Stegastes partitus affect their survivorship (Booth \& Hixon 1999). Surviving juveniles of 2 coral reef species, Thalassoma bifasciatum and Halichoeres bivittatus, suffer size-selective mortality during early post-settlement (Searcy \& Sponaugle 2001). Fast-growing larvae of Paralabrax clathratus experience enhanced survival during the first days after settlement relative to larvae with slower growth (Shima \& Findlay 2002). Individuals of Neopomacentrus filamentosus that survive intense selective mortality after settlement are the largest members of the cohort at hatching and grow faster during planktonic life (Vigliola \& Meekan 2002). Other studies, both in marine (e.g. Rosenberg \& Haugen 1982, Crecco et al. 1983, Hovenkamp 1992, McCormick \& Molony 1992, Suthers et al. 1992) and in freshwater fishes (e.g. Rice et al. 1987, Titus \& Mosegaard 1991, Ludsin \& de Vries 1997) report a similar pattern.

Furthermore, these studies emphasise the size advantages that allowed post-settlers to survive the settlement period, when mortality caused by predation is intense (Macpherson et al. 1997, Caselle 1999, Schmitt \& Holbrook 1999). However, our results showed that these size advantages were not always applicable in the 2 species of Symphodus. The differences observed in size-at-hatching were not clearly reflected in the other indices. Therefore, we conclude that in our case the 'bigger is better' hypothesis (Miller et al. 1988) is not applicable, and that larval quality (measured as size-at-hatching) is the best indicator of juvenile viability.

The absence of a consistent trend for selective mortality on the basis of all larval traits has been reported for other species (Searcy \& Sponaugle 2001). Most studies that have analysed size-selective mortality were performed in species that settle in shoals of distinct sizes, with moderately long planktonic periods (usually $>3 \mathrm{wk}$ ) (see references above). The 2 species of Symphodus have a very short planktonic larval duration (PLD $=9$ to $12 \mathrm{~d}$ ), they settle individually into branching algae, which are used for hiding (Raventos \& Macpherson 2005), and remain motionless until they leave the algae when they reach a size of ca. 2 to $3 \mathrm{~cm}$ ( $>40 \mathrm{~d}$ old), when predation pressure is presumably low (Macpherson et al. 1997, Caselle 1999). Although larvae and new settlers of Symphodus suffer predation by numerous species (e.g. shrimps, crabs, cannibalism, other fishes, authors' pers. obs.), the short PLD and hiding behaviour could diminish the advantages of rapid larval growth (McCormick 1998, Shima \& Findlay 2002).

The effect of size-at-hatching in the posterior sizeselective mortality emphasises the importance of larval condition in the early life of these species (McCormick
1998, Searcy \& Sponaugle 2001). The relationship between larval size-at-hatching and the size of the eggs (Chambers 1997, Coleman \& Galvani 1998) is influenced by maternal size and condition (Chambers et al. 1989, Marteinsdottir \& Steinarsson 1998, Ouellet et al. 2001). As several authors have pointed out (Ludsin \& de Vries 1997, Vigliola \& Meekan 2002, McCormick 2003), the condition of parental stocks, through the maternal effect on larval size-at-hatching, could have a considerable effect on settlement and recruitment. Unfortunately, the potential relationships between maternal and larval conditions are unknown for Symphodus roissali and S. ocellatus, and future research is needed on these aspects (see also Bergenius et al. 2002, Wilson \& Meekan 2002).

Acknowledgements. We would like to thank T. García-Rubies and $\mathrm{T}$. Alcoverro for insightful discussions during the preparation of the text and I. Abreu for boat research assistance. This research was funded by project CICYT-MAR99-0873.

\section{LITERATURE CITED}

Anderson JT (1988) A review of size-dependent survival during pre-recruit stages of fishes in relation to recruitment. J Northwest Atl Fish Sci 8:55-66

Bailey KM, Houde ED (1989) Predation on eggs and larvae of marine fishes and the recruitment problem. Adv Mar Biol 25:1-83

Bergenius MAJ, Meekan MG, Robertson DR, McCormick MI (2002) Larval growth predicts the recruitment success of a coral reef fish. Oecologia 131:521-525

Booth DJ, Hixon MA (1999) Food ration and condition affect early survival of the coral reef damselfish, Stegastes partitus. Oecologia 121:364-368

Caley MJ, Carr MH, Hixon MA, Hughes TP, Jones GP, Menge BA (1996) Recruitment and the local dynamics of open marine populations. Annu Rev Ecol Syst 27:477-500

Caselle JE (1999) Early post-settlement mortality in a coral reef fish and its effects on local population size. Ecol Monogr 69:177-194

Chambers RC (1997) Environmental influences on egg and propagule sizes in marine fishes. In: Chambers RC, Trippel EA (eds) Early life history and recruitment in fish populations. Chapman \& Hall, London, p 63-102

Chambers RC, Miller TJ (1995) Evaluating fish growth by means of otolith increment analysis: special properties of individual-level logitudinal data. In: Secor DH, Dean JM, Campana SE (eds) Recent developments in fish otolith research. University of South Carolina Press, Columbia, $\mathrm{SC}, \mathrm{p}$ 155-175

Chambers RC, Leggett WC, Brown JA (1989) Egg size, female effects, and the correlations between early life history traits of capelin, Mallotus villosus: an appraisal at the individual level. Fish Bull 87:515-523

Coleman RM, Galvani AP (1998) Egg size determines offspring size in neotropical cichlid fishes (Teleostei: Cichlidae). Copeia 1998:209-213

Crecco V, Savory T, Gunn L (1983) Daily mortality rates of larval and juvenile shad (Alosa sapidissima) in the Connecticut River with changes in year-class strength. Can J Fish Aquat Sci 40:1719-1728 
Doherty P, Fowler T (1994) An empirical test of recruitment limitation in a coral reef fish. Science 263:935-939

García-Rubies A, Macpherson E (1995) Substrate use and temporal pattern of recruitment in juvenile fishes of the Mediterranean littoral. Mar Biol 124:35-42

Hare JA, Cowen RK (1997) Size, growth, development, and survival of the planktonic larvae of Pomatomus saltatrix (Pisces: Pomatomidae). Ecology 78:2415-2431

Harmelin-Vivien ML, Francour P (1992) Trawling or visual censuses? Methodological bias in the assessment of fish populations in seagrass beds. PSZN I: Mar Ecol 13:41-51

Hovenkamp F (1992) Growth-dependent mortality of larval plaice Pleuronectes platessa in the North Sea. Mar Ecol Prog Ser 82:95-101

Leggett WC, DeBlois E (1994) Recruitment in marine fishes: is it regulated by starvation and predation in the egg and larval stages? Neth J Sea Res 32:119-134

Litvak MK, Leggett WC (1992) Age- and size-selective predation on larval fishes: the bigger-is-better hypothesis revisited. Mar Ecol Prog Ser 81:1-24

Ludsin SA, de Vries DR (1997) First-year recruitment of largemouth bass: the interdependency of early life stages. Ecol Appl 7:1024-1038

Macpherson E, Biagi F, Francour P, Garcia-Rubies A and 6 others (1997) Mortality of juvenile fishes of the genus Diplodus in protected and unprotected areas in the western Mediterranean Sea. Mar Ecol Prog Ser 160:135-147

Macpherson E, Gordoa A, Gracia-Rubies A (2002) Biomass size spectra in littoral fishes in protected and unprotected areas in the NW Mediterranean. Estuar Coast Shelf Sci 55: $777-788$

Marteinsdottir G, Steinarsson A (1998) Maternal influence on the size and viability of Iceland cod Gadus morhua eggs and larvae. J Fish Biol 52:1241-1258

Maxwell SE, Delaney HD (1990) Designing experiments and analyzing data: a model comparison perspective. Wadsworth, Belmont, CA

McCormick MI (1998) Condition and growth of reef fish at settlement: is it important? Aust J Ecol 23:258-264

McCormick MI (2003) Consumption of coral propagules after mass spawning enhances larval quality of damselfish through maternal effects. Oecologia 136:37-45

McCormick MI, Molony BW (1992) Effects of feeding history on the growth characteristics of a reef fish at settlement. Mar Biol 114:165-173

Meekan MG, Fortier L (1996) Selection for fast growth during the larval life of Atlantic cod Gadus morhua on the Scotian shelf. Mar Ecol Prog Ser 137:25-37

Miller TJ, Crowder LB, Rice JA, Marschall EA (1988) Larval size and recruitment mechanisms in fishes: toward a conceptual framework. Can J Fish Aquat Sci 45:1657-1670

Ouellet P, Lambert Y, Berube I (2001) Cod egg characteristics and viability in relation to low temperature and maternal nutritional condition. ICES J Mar Sci 58:672-686

Pepin P, Shears TH, Lafontaine Y de (1992) Significance of body size to the interaction between a larval fish (Mallotus villosus) and a vertebrate predator (Gasterosteus aculeatus). Mar Ecol Prog Ser 81:1-12

Raventos N (2004) Wave action affects nesting activity in the littoral fish five-spotted wrasse (Symphodus roissali, Labridae). Sci Mar 68:257-264

Raventos N, Macpherson E (2001) Planktonic larval duration and settlement marks on the otoliths of Mediterranean littoral fishes. Mar Biol 138:1115-1120

Raventos N, Macpherson E (2005) Environmental influences on temporal patterns of settlement in two littoral labrid fishes in the Mediterranean Sea. Estuar Coast Shelf Sci (in press)

Rice JA, Crowder LB, Holey ME (1987) Exploration of mechanisms regulating larval survival in Lake Michigan bloater: a recruitment analysis based on characteristics of individual larvae. Trans Am Fish Soc 116:703-718

Rosenberg AA, Haugen AS (1982) Individual growth and size-selective mortality of larval turbot (Scophthalmus maximus) reared in enclosures. Mar Biol 72:73-77

Sabatés A, Zabala M, Garcia-Rubies A (2003) Larval fish communities in the Medes Islands marine reserve (north-west Mediterranean). J Plankton Res 25:1035-1046

Schmitt RJ, Holbrook SJ (1999) Mortality of juvenile damselfish: implications for assessing processes that determine abundance. Ecology 80:35-50

Searcy SS, Sponaugle S (2000) Variable larval growth in a coral reef fish. Mar Ecol Prog Ser 206:213-226

Searcy SS, Sponaugle S (2001) Selective mortality during the larval-juvenile transition in two coral reef-fishes. Ecology 82:2452-2470

Shima JS, Findlay AM (2002) Pelagic larval growth rate impacts benthic settlement and survival of a temperate reef fish. Mar Ecol Prog Ser 235:303-309

Sogard SM (1997) Size-selective mortality in a juvenile stage of teleost fishes: a review. Bull Mar Sci 60:1129-1157

Suthers IM, Fraser A, Frank KT (1992) Comparison of lipid, otolith and morphometric condition indices of pelagic juvenile cod Gadus morhua from the Canadian Atlantic. Mar Ecol Prog Ser 84:31-40

Titus RG, Mosegaard H (1991) Selection for growth potential among migratory brown trout (Salmo trutta) fry competing for territories: evidence from otoliths. Can J Fish Aquat Sci 48:19-27

Van den Berghe EP (1990) Variable parental care in a labrid fish: how care might evolve. Ethology 84:319-333

Vigliola V, Meekan MG (2002) Size at hatching and planktonic growth determine post-settlement survivorship of a coral reef fish. Oecologia 131:89-93

Vigliola L, Harmelin-Vivien M, Meekan MG (2000) Comparison of techniques of back-calculation of growth and settlement marks from the otoliths of three species of Diplodus from the Mediterranean Sea. Can J Fish Aquat Sci 57:1291-1299

Von Ende CN (1993) Repeated-measures analysis: growth and other time-dependent measures. In: Scheiner SM, Gurevitch J (eds) Design and analysis of ecological experiments. Chapman \& Hall, London, p 113-137

Wellington GM, Victor BC (1992) Regional differences in duration of the planktonic larval stage of reef fishes in the eastern Pacific Ocean. Mar Biol 113:491-498

Wilson DT, McCormick MI (1999) Microstructure of settlement-marks in the otoliths of tropical reef fishes. Mar Biol 134:29-41

Wilson DT, Meekan MG (2002) Growth-related advantages for survival to the point of replenishment in the coral reef fish Stegastes partitus (Pomacentridae). Mar Ecol Prog Ser 231:247-260

Zar JH (1984) Biostatistical analysis. Prentice-Hall International, Englewood Cliffs, NJ

Submitted: March 3, 2004; Accepted: September 7, 2004 Proofs received from author(s): December 9, 2004 